\title{
Neo-patrimonialism and Policy Processes: Lessons from the Southern African Food Crisis
}

\section{Elizabeth Cromwell and Allan Chintedza*}

\section{Introduction}

In the 1990s economic liberalisation replaced state support for agriculture across much of Southern Africa. As well as reducing costs, it was assumed that liberalisation would ensure food availability and access to food through positive effects on production and trade incentives and on incomes. However, subsequent experience has not matched this vision: in December 2002, 16 million people in the region (30 per cent of the population) were declared in danger of running out of food.

But 2001-3 was not a one-off crisis caused solely by two poor seasons. ${ }^{1}$ Human impacts were broader and deeper because of underlying chronic food insecurity: available estimates suggest that around half of the 16 million people at risk in 2002 are food insecure every year. ${ }^{2}$ Over the last decade,
Southern Africa has made little progress towards the Millennium Development Goal for reduction in hunger (Table 1). Why is this so?

Food production across much of Southern Africa, far from responding to liberalisation, has declined over the last decade. With population growth at 2-3 per cent per year, this represents a significant decline in per capita domestic food availability. With strong linkages between growth in farming and related sectors in rural areas, the decline in production has constrained rural growth and incomes, limiting people's means to buy food. In this context of declining domestic food availability and declining real incomes, market shortages quickly translate into increased prices unaffordable for many people.

\section{Table 1: Progress Towards Hunger Millennium Development Goal}

\begin{tabular}{|c|c|c|c|c|c|c|}
\hline & \multicolumn{3}{|c|}{$\begin{array}{l}\text { Prevalence of child malnutrition } \\
\text { (\% U5 children below } 2 \text { SD mean } \\
\text { weight for age) }\end{array}$} & \multicolumn{3}{|c|}{$\begin{array}{l}\text { Prevalence of undernourishment } \\
\text { (\% population below FAO } \\
\text { recommended daily calorie intake) }\end{array}$} \\
\hline & 1990 & 1995 & 2001 & 1990 & 1995 & 2001 \\
\hline Lesotho & 15.8 & 21.4 & 17.8 & 27.0 & 26.0 & 25.0 \\
\hline Malawi & 27.6 & 29.9 & 25.4 & 49.0 & 39.0 & 33.0 \\
\hline Mozambique & - & 27.0 & - & 69.0 & 62.0 & 53.0 \\
\hline Zambia & 25.2 & 23.5 & 28.2 & 45.0 & 47.0 & 50.0 \\
\hline Zimbabwe & 11.5 & 15.5 & 13.0 & 43.0 & 44.0 & 39.0 \\
\hline
\end{tabular}

Source: Demographic and Health Surveys (www.measuredhs.com); FAO (2003).

IDS Bulletin Vol 36 No 2 June 2005 @ Institute of Development Studies 


\section{The "taming" of economic reform in Southern Africa}

Not all the blame for Southern Africa's food insecurity lies with the principle of economic liberalisation. For example, the Mozambique government does not intervene in private sector movement of grain, it has minimal strategic grain reserve capacity, yet the numbers of people short of food during 2001-3 were the lowest in absolute and proportionate terms across the region (SADC FANR VAC 2003).

Some blame must lie with the HIV/AIDS epidemic, which now affects more than 30 per cent of adults in some Southern African countries. HIV/AIDS has impacts on food production capacity and income to buy food, and increases requirements for quantity and quality of food (see Drinkwater, this IDS Bulletin).

However, there is a strong case for suggesting that the practice of economic liberalisation has been a major factor contributing to food insecurity in Southern Africa. This has two components. First, mistakes have been made in applying economic liberalisation in the circumstances of Southern Africa. In particular, the extent and severity of the "low-level equilibrium trap" limiting private sector activity has been significantly underestimated (see Dorward et al., this IDS Bulletin).

Second, there has been a "taming" of economic liberalisation in Southern Africa, partly in response to the perceived political harm posed by reform (Jayne et al. 2002; Bird et al. 2003). Evidence and analysis contributed to the Forum for Food Security in Southern Africa suggest that a plausible explanation for this lies in the continued influence of neo-patrimonialism on policy implementation in the region. This article focuses on how this can be addressed.

\section{Policy processes: distinguishing the "what" from the "how"}

Policy processes are usually considered to include agenda setting, policy formulation, decisionmaking, policy implementation and policy evaluation. ${ }^{3}$ This goes beyond documents and legislation to include activities on the ground. Only if both agenda setting and formulation (policy content) and decision-making and implementation are sound, will policy processes have the potential to deliver positive change. However it has been compellingly argued that policy research on African agriculture has been overly concerned with the "what" of policy, at the expense of the "how" of processes and implementation (see Omamo 2003; Keeley and Scoones 2003; also Scoones, this IDS Bulletin).

\section{Politics and policy implementation}

Widely mentioned reasons for poor implementation of good policies include lack of financial and human resources and inadequate incentive structures. The influence of politics - and particularly the configurations making up neo-patrimonial politics (see below) - has received much less attention. ${ }^{4} \mathrm{We}$ are not suggesting these other reasons should be ignored; rather, we seek to demonstrate that neopatrimonialism also contributes to poor implementation of food security policies in Southern Africa and this needs to be acknowledged more explicitly.

The concept of neo-patrimonialism has been used in studies of the political science of Africa since the 1970s, and is increasingly accepted as part of the political landscape within the region (see Olukushi, this IDS Bulletin). A neo-patrimonial state is a "hybrid regime", where modern bureaucracies coexist beside "political authority [that] ... is based on the giving and granting of favours ... that go from the village level to the highest reaches of the central state' (van de Walle 2001: 51). That aid can support neo-patrimonial states is becoming increasingly obvious.

The authority of the ruling regime depends on the distribution of socio-economic resources to clients, rather than on "legal-rational" mechanisms such as the rule of law, meritocracy and political accountability. Power is centralised around a single individual and their close associates, with ultimate control over most clientelist networks. These people 'personally exert discretionary power over a big share of the state's resources' (van de Walle 2001: 52). Government is accountable primarily for its performance as dispenser of patronage, and not for the implementation of policies. Those that do not belong to clientelist networks suffer a significant lack of voice in policy processes. In much of subSaharan Africa, patrimonial practices of personalised exchange, clientelism and political corruption have become internalised in formal political institutions and provide 'essential operating codes for politics' (Bratton and van de Walle 1997: 63). 
Figure 1: The RAPID Framework

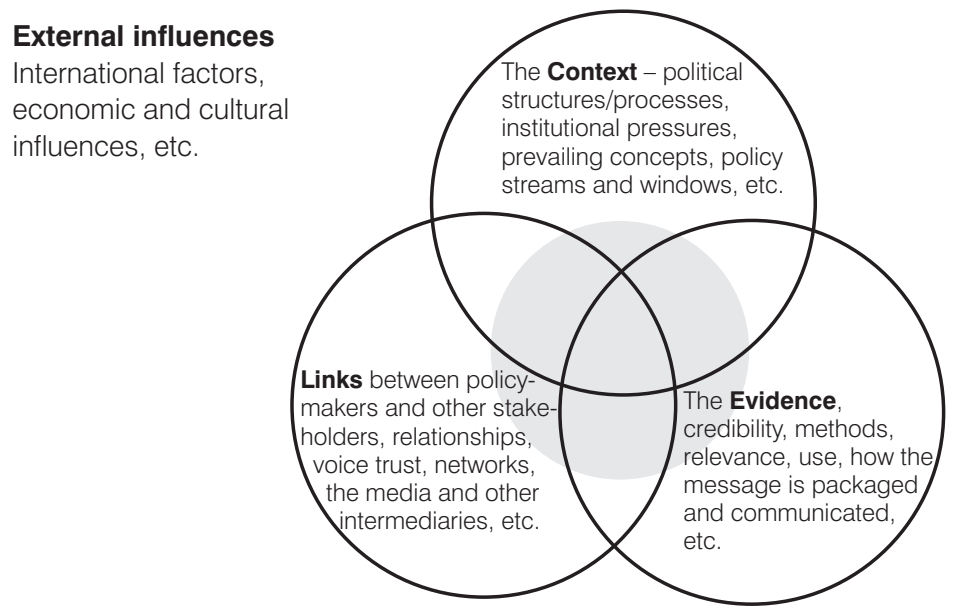

A recent review of politics and food security in five countries in Southern Africa (Bird et al. 2003) indicates that, even when strengthening long-term food security is a clearly stated policy objective and policies have been formulated to address this, implementation is significantly determined by the opportunity to support clientelist relations. For example, state-subsidised agricultural credit in Zambia has represented a form of patronage to small-scale farmers and was seen to be an important mechanism for ensuring continued support for the ruling party in the run-up to the 1996 elections. While the distribution of cheap credit was declared policy, there was a de facto policy of not enforcing repayments. These political priorities within a neopatrimonial setting had huge opportunity costs in terms of maintaining uneconomic maize production and diverting state resources from investment in long-term economic development.

Politics provides the context for policy-making in any country, and rightly so. However neopatrimonial politics have the distinctive quality of structuring policy implementation in a way that systematically diverts public resources for private gain. This frequently leads to inferior implementation, undermining development possibilities that are already restricted by social and economic constraints. In Southern Africa's case, the failure to stop eight million people from running the risk of food shortage each year.

\section{Changing policy processes: implications for development practice}

An important first step in creating a positive policy environment for addressing food security in Southern Africa is for all development partners to accept that neo-patrimonialism is a significant influence on policy implementation, and to act deliberately to control its influence.

How can this be done? To date, "lack of political will" to implement policy has either been treated as an exogenous variable in the policy process, or identified solutions have focused on direct intervention in the political process. The authors suggest there is a third line of attack focused on influencing policy processes. This builds on the RAPID (Research and Policy in Development) framework (see Figure 1; Young and Court 2004), according to which three broad groups of factors influence policy processes: the political context, the evidence for change, and the links between them. Evidence suggests that, while political context seems to be the most important influence on the policy process, outcomes can be influenced by provision of better evidence and links.

Attempts are being made to influence policy processes in this way, both within individual countries and within important regional institutions.

The Malawi case (Box 1) illustrates how building accountability and inclusivity into policy processes 


\section{Box 1: Food Security Policy Review Process in Malawi}

In February 2002, Malawi set up a national Joint Task Force (JTF) to deal with the food crisis and produce a revised long-term food and nutrition policy. In contrast to past government-dominated processes, the JTF included multiple stakeholders. A Food Security and Nutrition Policy Subcommittee (FSNPS) was charged with producing the revised national food and nutrition policy and facilitating ownership and participation.

Stakeholder consultations focused on sharing knowledge and insights, and building an evidence base among a linked group of actors and networks. Consultations included regional workshops for local government, traditional authorities and civil society. Community consultations were also held nationwide through the civil society agriculture network, using an adapted form of citizens' jury based on Malawi's traditional bwalo community discussion forum (CISANET 2004). A national workshop involved key stakeholders including community representatives and international experts. Parliamentary Committees on Agriculture and Public Accounts met to ensure the legislature is involved in the process and to build consensus. By early 2005, a policy and action plan was being agreed for presentation to Cabinet for the July 2005 Budget.

Overall, the JTF approach had positive results: it increased genuine cooperation in addressing the food crisis; and it increased leadership and commitment from government, who gained confidence from the multi-stakeholder approach. The consultation process was useful in ensuring the needs of different stakeholders were represented, especially the community consultation, which produced new insights into rural families' priority food security concerns. A key lesson on ownership was that the inter-Ministerial composition of the Task Force was crucial, given the problems experienced in the past with leadership on food and nutrition security issues in Malawi.

helps to improve effectiveness. In the same way, but at a broader, continental level, the peer review mechanism at the centre of the New Partnership for Africa's Development (NEPAD) provides an African voice on political and economic governance in participating countries, again building processes of accountability into the policy process, explicitly aimed at offsetting tendencies to neo-patrimonialism (see www.nepad.org/en/htm).

\section{Practical approaches}

Several techniques can be used to gather evidence about and publicise the influence of politics on the policy process and deviation from implementation plans. These include: political context mapping, to understand the nature of formal and informal policy processes at district or national level (Court and Cotterrell 2005, forthcoming); context assessment tools such as stakeholder mapping, influence mapping and triangle analysis (Start and Hovland 2004); and outcome mapping, which focuses on changes in behaviour, relationships, action and activities in target organisations. ${ }^{5}$

In many countries, there are very few formal associations autonomous from government, and civil society is weak and marginalised. Even where trade unions, community development associations and business associations exist, these are often marginalised from policy processes or co-opted by government into patron-client relations.

Increasing the flow of accessible information about proposed policies to the social groups that they affect can help these groups to exercise their rights. Successful examples of these include the Zambia Civil Society for Poverty Reduction's dissemination of translated summaries of Zambia's Poverty Reduction Strategy Paper (CSPR 2004) and the Malawi Economic Justice Network's economic and budget literacy project, which has distributed simplified versions of the National Budget and Malawi Poverty Reduction Strategy Paper (PRSP) to grassroots members, MPs, government officials and donors (MEJN 2005a).

Effective watchdog organisations are important for monitoring and publicising inappropriate activities. Formal watchdog organisations may be co-opted by the state, but organisations and mechanisms controlled by civil society organisations can be more successful. For example, in Malawi, the Board of the National Food Reserve Agency was weakened by political appointees who were unable to resist instructions to release grain from the Strategic Grain Reserve during 
the food crisis, in contravention of the agreed policy (Economic Resources Ltd and Ernst \& Young 2003). In contrast, the Malawi Economic Justice Network's Service Delivery Satisfaction Surveys have contributed to holding government to account for PRSP implementation (MEJN 2005b).

\section{External influences: implications for donors}

There are five important lessons from Southern Africa's experience regarding the contribution of donors to poor policy implementation:

1. Donors must invest in their own learning about the drivers of change in different political and economic systems. ${ }^{6}$ The "lack of political will" commonly cited as an implementation constraint is a manifestation of complex historical processes which vary from country to country. These underlying drivers need to be understood and addressed if the aid relationship is to contribute to taming rather than fuelling neo-patrimonial tendencies to divert policy implementation.

2. Donors must be willing to invest in long-term market development, not only to bring the potential benefits of economic liberalisation to regions suffering from the low-level equilibrium trap (see Dorward et al., this IDS Bulletin), but also to counter neo-patrimonial tendencies towards exerting discretionary power over a big share of state resources.

3. Donors should invest in and be supportive of approaches and tools to increase the voice and effectiveness of civil society in policy processes at national and regional level.

\section{Notes}

* In this article evidence is drawn from five countries in Southern Africa, collected by the Forum for Food Security in Southern Africa and personal experience of Malawi's current National Food and Nutrition Security Policy review. Responsibility for specific suggestions in this article lies with the authors alone. We are indebted to the Forum stakeholders, and to the UK Department for International Development for funding. Forum documents are available at www.odi.org.uk/ food-security-forum (accessed April 2005).

1. The poor harvests were moderate in historical perspective: mostly 10-25 per cent shortfall on the previous five-year average, compared with the 65 per cent shortfall in 1991-2 (FFSSA 2004).

2. There are few published estimates. This figure comes from CARE and is supported by country level estimates for Malawi in Levy (2003).
4. Donors must consider the patronage potential of different policy instruments. For example, the potential for inefficiencies in supply-side instruments, such as subsidised food and agricultural inputs, is high. In Southern Africa, significant local-level diversion has been recorded in Malawi, for example, in the Targeted Inputs Programme (Levy and Barahona 2002). Direct welfare transfers such as allowances and pensions could strengthen access and be more efficient (Harvey 2005).

5. All these considerations are relevant to current debates on aid effectiveness. ${ }^{7}$ Donors have moral and economic obligations to ensure that aid funds can be used effectively: decisions about aid volumes, criteria for allocating aid resources, and choice of aid instruments need to bear in mind the likely influence of neo-patrimonialism on the policy process. Donors must accept that they are sometimes part of the problem, by their channelling of large aid flows through weak government systems.

These lessons mean that donors need to focus not only on increasing aid, but also on the political context of aid delivery, and on the support of policy instruments that are effective for alleviating poverty and strengthening food security in the political reality of poor countries. These lessons are particularly relevant in 2005, when the Africa Commission is reporting on how rich nations can best support Africa's development efforts, and the UN Millennium Review is considering how best the international community can support progress towards achievement of the Millennium Development Goals.

3. For more on policy processes, see www.odi.org.uk/rapid. Also see Hill (1997) for a reader and Keeley and Scoones (2003) for an African perspective.

4. See Bird et al. (2003), from which much of the material in this section is drawn.

5. See http://web.idrc.ca/en/ev-9330-201-1-DO_TOPIC. html for more on outcome mapping.

6. For more on drivers of change analysis, see www.grcexchange.org/g_themes/politicalsystems_drivers.html

7. For a summary of aid effectiveness issues in Africa, see www.odi.org.uk/publications/opinions/30_aid_africa_jan 05.html 


\section{References}

Bird, K., Booth, D. and Pratt, N., 2003, Food Security Crisis in Southern Africa: The Political Background to the Policy Failure, London: Forum for Food Security in Southern Africa, Overseas Development Institute

Bratton, M. and van de Walle, N., 1997, Democratic Experiments in Africa: Regime Transitions in Comparative Perspective, Cambridge: Cambridge University Press

CISANET, 2004, The People's Voice! A Community Consultation Report on Malawi Food and Nutrition Security Policy Formulation Process, Lilongwe: Civil Society Agricultural Network

Court, J. and Cotterrell, L., 2005 forthcoming, 'What political and institutional context issues matter for bridging research and policy? A literature review and discussion of data collection approaches', Working Paper, London: Overseas Development Institute

Court, J. and Young, J., 2003, 'Bridging research and policy: insights from 50 case studies', ODI Working Paper 213, www.odi.org.uk/publications/ working_papers/wp213.pdf

CSPR, 2004, PRSP: kuceptsa umphawi mu Zambia!, Lusaka: Civil Society for Poverty Reduction

Economic Resources Ltd and Ernst \& Young, 2003, 'National Food Reserve Agency: external audit of NFRA and management of Malawi's national grain stocks', mimeo, Aide Memoire/Executive Summary

FAO, The State of Food Insecurity in the World, 2003 ftp://ftp.fao.org/docrep/fao/006/j0083e/j0083e00 .pdf

FFSSA, 2004, Achieving Food Security in Southern Africa: Policy Issues and Options, London: Forum for Food Security in Southern Africa, Overseas Development Institute

Harvey, P., 2005, 'Cash and vouchers in emergencies', Humanitarian Policy Group Discussion Paper, London: Overseas Development Institute

Hill, J. (ed.), 1997, The Policy Process: A Reader, London: Prentice Hall
Jayne, T., Govereh, J., Mwanaumo, A., Nyoro, J. and Chapoto, A., 2002 'False promise or false premise? The experience of food and input market reform in Eastern and Southern Africa', World Development, Vol 30 No 11: 1967-85

Keeley, J. and Scoones, I., 2003, Understanding Environmental Policy Processes. Cases from Africa, London: Earthscan

Levy, S., 2003, 'Starter packs and hunger crises: a briefing for policy makers on food security in Malawi - key findings from the evaluation of Starter Pack/Targeted Inputs Programme (TIP)', mimeo, Calibre Consultants, Reading (calibre.consultants@btopenworld.com),CD format: contact author for copies

Levy, S. and Barahona, C., 2002, 2001-02 Targeted Inputs Programme (Tip) - Main Report of the Evaluation Programme, Reading: Statistical Services Centre, University of Reading

MEJN, 2005a, Organisational Brief, Lilongwe, Malawi: Malawi Economic Justice Network

MEJN, 2005b, 'Evidence: civil society undoubted tool for effective advocacy - the case for Malawi', presentation at seminar on CSOs, Evidence and Policy Influence, 10 February, Lilongwe, Malawi

Omamo, S., 2003, 'Policy research on African agriculture: trends, gaps and challenges', Research Report 21, The Hague: International Service for National Agricultural Research

SADC FANR VAC, 2003, Regional Emergency Food Security Assessment Report: January, Harare: Regional Vulnerability Assessment Committee Start, D. and Hovland, I., 2004, Tools for Policy Impact: a Handbook for Researchers, London: Overseas Development Institute

van de Walle, N., 2001, African Economies and the Politics of Permanent Crisis, 1979-1999, Cambridge: Cambridge University Press

Young, J. and Court, J., 2004, 'Bridging research and policy in international development: an analytical and practical framework', RAPID Briefing Paper 1, London: Overseas Development Institute 